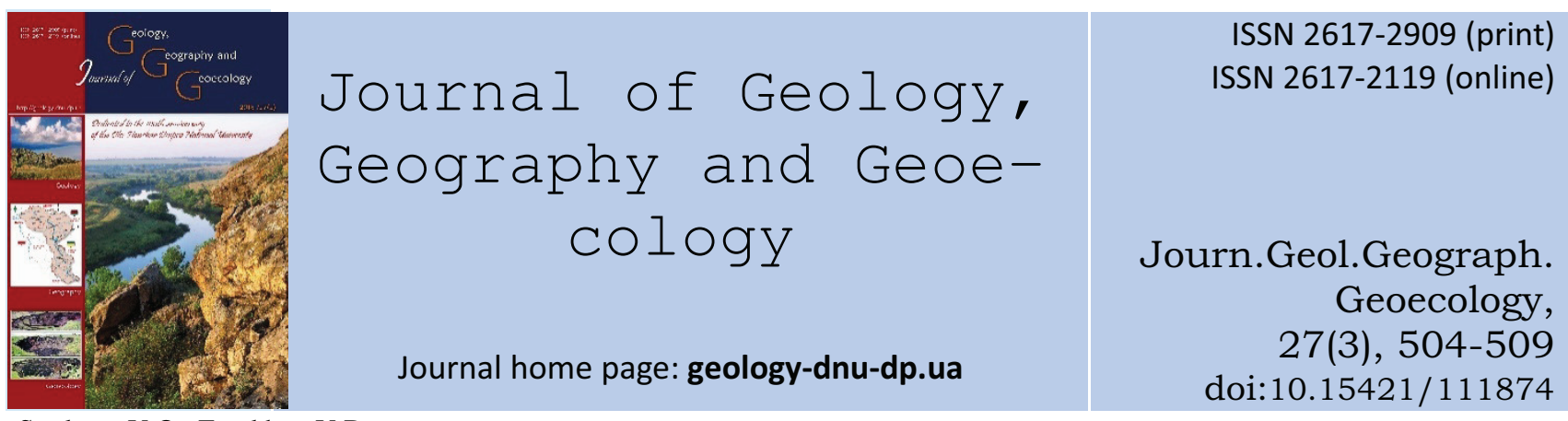

Streltsov V.O., Evtekhov V.D.,

Evtekhova A.V., Smirnova H.Ya.

Journ.Geol.Geograph.Geoecology, 27(3), 504-509

\title{
Geological position of riebeckite-containing magnetite ores of Krivoy Rog basin
}

\author{
Streltsov V.O., Evtekhov V.D., Evtekhova A.V., Smirnova H.Ya. \\ Krivoy Rog National University, 37, Pushkina Str., Krivoy Rog, 50002, Ukraine \\ E-mail: misterstrelcov90@gmail.com,evtekhov@gmail.com, eva.anna23@gmail.com
}

Received 06.09.2018;

Received in revised form 27.10.2018;

Accepted 19.11.2018

Abstract. The geological position of the riebeckite metasomatites at the Pervomayskoye, Annovskoye, Gleyevatskoye, Valyavkinskoye, Inguletskoye, Petrovskoye and Artemovskoye deposits of the Krivbas is controlled by faults serving as channels for metasomatizing solution filtrations. This is confirmed by a significant loss of riebeckite metasomatites abundance moving south and north of the central part of the Pervomayskoye deposit, the position of which corresponds to the intersection of two deep faults that are: the submeridional Krivoy RogKremenchug and the sublatitudinal Devladovo ones. In the productive strata of other deposits, the distribution of riebeckite metasomatites is much lower in comparison with the Pervomayskoye deposit, but their position is also determined by faults position.The fifth and sixth ferruginous horizons are characterized by the maximum distribution of riebeckite metasomatites within the Pervomayskoye deposit and form the productive iron ore rock mass. They contain ferruginous quartzites with the highest iron content, composition of which is optimal for active manifestation of riebeckite metasomatism. The process of riebeckitization occurred to much lesser extentin the stratigraphic horizons that underlie and overlay the productive rock mass and which are composed of schists and low-iron magnetite-silicate quartzites.Silicateless (micaceous hematite-magnetite, magnetite) quartzites were subjected to the most intensive riebeckitization in the ferruginous horizons: the content of riebeckite metasomatites here makes up $60-80 \%$ of the volume of ore layers. The composition of the sodium amphibole is close to stoichiometric one here. In the layers composed of cummingtonite-magnetite and magnetite-cummingtonite quartzites, the amount of riebeckite metasomatites is much lower and makes up 10-30\% of their total volume. The sodium amphibole is represented here by magnesioriebeckite. Similar regularities in the distribution of riebeckite metasomatites are also typical for ferruginous horizons of all iron ore deposits in the Krivoy Rog basin.

Keywords: banded iron formation, Krivoy Rog basin, riebeckite metasomatites, geological position of metasomatites.

\section{Геологічна позиція рибекіт-вмісних магнетитових руд Криворізького басейну}

\author{
Стрельцов В.О., Євтєхов В.Д., Свтєхова А.В., Смірнова Г.Я.
}

Криворізький начіональний університет, 37, вул. Пушкіна, м. Кривий Ріг, 50002, Украӥна E-mail:misterstrelcov90@gmail.com,evtekhov@gmail.com, eva.anna23@gmail.com

Анотація. Геологічна позиція рибекітових метасоматитів Первомайського, Ганнівського, Глеюватського, Валявкинського, Інгулецького, Петрівського, Артемівського родовищ Кривбасу контролюється розривними порушеннями, які були каналами фільтрації метасоматизуючих розчинів. Підтвердженням цього є істотне зменшення представленості рибекітових метасоматитів 3 просуванням на південь і північ від центральної частини Первомайського родовища, позиція якого відповідає ділянці перетину двох глибинних розломів: субмеридіонального Криворізько-Кременчуцького та субширотного Девладівського. У продуктивних товщах інших родовищ поширення рибекітових метасоматитів значно нижче в порівнянні $з$ Первомайським родовищем, але їх положення також визначається позицією розривних порушень.Максимальним поширенням рибекітових метасоматитів у межах Первомайського родовища характеризуються п'ятий і шостий залізисті горизонти, які складають його продуктивну залізорудну товщу. Саме в них присутні залізисті кварцити з найбільш високим вмістом заліза, оптимальні за складом для активного прояву рибекітового метасоматозу. У стратиграфічних горизонтах, які підстеляють і перекривають продуктивну товщу і які складені сланцями та низькозалізистими магнетит-силікатними кварцитами, рибекітізація відбувалась значно слабкіше.В залізистих горизонтах найбільш інтенсивної рибекітизації зазнали безсилікатні (залізнослюдко-магнетитові, магнетитові) кварцити: вміст рибекітових метасоматитів у їх верствах становить 60-80\% від об'єму рудних верств. Склад натрієвого амфіболу тут близький до стехіометричного. У верствах, складених кумінгтоніт-магнетитовими i магнетит-кумінгтонітовими кварцитами, кількість рибекітових метасоматитів істотно нижча - 10-30\% від їх загального 
об’єму. Натрієвий амфібол представлений тут магнезіорибекітом. Аналогічні закономірності поширення рибекітових метасоматитів характерні також для залізистих горизонтів усіх залізорудних родовищ Криворізького басейну.

Ключові слова: залізисто-кремниста формачія, Криворізький басейн, рибекітові метасоматити, геологічна позиція метасоматитів.

Importance. Riebeckitized magnetite quartzites constitute a significant part of the productive strata at the Pervomayskoye, Annovskoye, Inguletskoye, Petrovskoye, and Artemovskoye deposits in the Krivoy Rog basin. Their formation is associated with epigenetic process of sodium metasomatism, which is about 1.8 billion years old and which occurred at an interval of about 400 million years after the dynamothermal metamorphism of the rocks of the banded iron formation (2.2 billion years). Riebeckitization was accompanied by the migration of mineral matter, mineral formation, substitution and recrystallization of individuals and aggregates of metamorphogenic minerals, changes in the textures and structure of magnetite quartzites and, consequently, their preparability.

In recent years, the demand for iron ore raw materials has significantly decreaseddue to the decline in world industry. This caused an increase in the requirements to the quality of iron ore concentrate produced by the Kryvbas Ore Mining and BeneficiationWorks. Currently, the average iron content of the concentrate is about 65 mass $\%$, but there is a challenging need for the development of technologies ensuring an increase in this indicator up to 68-69 mass \%. Main directions of this work area reapprisal of the mineral and raw materials base of iron ore deposits, correcting existing ideas about the influence of mineralogical indices on ore beneficiation, updating mineraltechnological classifications of ores, compilinggeological, mineralogical, geologicaltechnological maps of deposits basing on the data; developing optimal ore mining technologies, ore blending before feedingto beneficiation plants.

Riebeckitized magnetite quartzites are the main mineral variety of ores at Pervomayskoye, Petrovskoye, and Artemovskoye deposits - they account for up to $60 \%$ of the total mass of the productive strata at these deposits. During the last 20 years, a significant amount of new data has been accumulated on the mineral, chemical composition of the riebeckite metasomatites, geological position and morphology of the depositsdue to operational geological exploration and case studies. It became necessary to generalize and analyze these data in order to take them into account in solving theoretical issues and practical problems. It contributes to scientific and applied relevance of the research carried out by the authors.
Analysis of the results of previous works. Riebeckite metasomatites were the subject of several previous studies. Issues of their geological position, structure of metasomatic bodies were considered in the works (Polovinkina, 1953;Eliseyev, e. a., 1961;Aleksandrov, 1963;Kushev,1972;Nikolskiy, 1973;Evtekhov, e. a., 1980;Evtekhov, e. a., 1988;Pirogov, e. a.,1989; Chadwick, e. a.,1986).The authors came to the conclusion of regularities existing in the arrangement of the bodies of riebeckite metasomatites, they are as follows: 1) the overwhelming majority of them tendsspatially towards the ferruginous horizons of the Saksagan suite; 2) ferruginous quartzites of the central zones, as well as cummingtonite-magnetite, magnetitecummingtonite quartzites of the peripheral zones of ferruginous horizons, were subject of maximum riebeckitization; 3) the position of the bodies of riebeckite metasomatites in the sections of the ferruginous horizons is controlled byfaulting, which played the role of supply channels for metasomatizing carbon dioxide-sodium hydrothermal solutions. Analysis of the possibility of using these data for conducting detailed mineralogical and technological studies and mapping of deposits indicates their insufficiency and the need for a deeper study of geological positionpeculiarities of the riebeckite metasomatites bodies within the productive strata of the deposits.

The aim of the authors of this article was to generalize existing ideas about the localization of riebeckite metasomatites, to update the data with the results of our own observations, to analyze general information, and to develop a multilevel system of information about the position of riebeckite metasomatites.

The results of published mineralogical studies, file materials of Krivoy Rognational university,Krivoy Rogcomplex geological party, the Northern geological prospecting party of "Ukrchermetgeology", geological services of Ingulets (InGOK), the Central (CGOK) and the Northern (SevGOK) Ore Mining and Processing Works have been usedas a source material. Information on chemical and mineral composition, structure, texture of primary magnetite quartzites and riebeckite metasomatites, peculiarities of their texture, structure, morphology and localization of metasomatic bodies has been taken into consideration. The authors have created a bank of initial data, have made their gene- 
ralization and analysis using approved software products.

The results obtained and their discussion. The Krivoy Rog basin. Previous studies have reported an uneven distribution of riebeckite metasomatites within different iron ore regions and deposits of Krivbas (Eliseyev, e. a., 1961;Aleksandrov, 1963; Kushev,1972; Pirogov, e. a., 1989). Most of the researchers have noted the maximum distribution of metasomatites in the strata of the ferruginous rocks of the Zheltorechenskoye, Pervomayskoye and Annovskoye deposits, which belong to the Northern iron ore region of Krivoy Rog basin and Petrovskoye, Artemovskoye deposits of the Right-bank iron ore district.

They have also noted their local presence in the Saksagan suite of the Inguletskoye, Gleyevatskoye, and Valyavkinskoye deposits and some deposits that are under development by the mines of the Saksagan iron ore district. One of the authors of this publication calculated the quantitative indicators for the distribution of sodium metasomatites after the data of productive strata study of 14 deposits of high-grade and low-grade iron ores of the Krivbas (Evtekhov, e. a., 1980;Evtekhov, e. a., 1988). In recent years, the proportion between me- tasomatically altered and unaltered iron ores has changed due to the advancement of open-pit and underground mine workings. Based on the results of quantitative calculations carried out by the authors of this article for the productive strata of the same 14 deposits, information on the distribution of sodium (aegirine, riebeckite, albite) metasomatites in their profiles as of the end of 2015 was updated (Table 1, fig. 1).

The obtained results confirm the previously published data on the very high representation of riebeckite metasomatites in the the productive strata of the Pervomayskoye and Annovskoye deposits, which are being developed by SevGOK. Here, the riebeckite metasomatites compose $30-44 \%$ of the volume of the fifth and sixth ferruginous horizons. Like the previous authors, we link the localization of metasomatites tointersecting (sublatitudinal) faults of Devladovo deep fault system. This is confirmed by a significant decrease in the representation of riebeckite metasomatites moving south and north of the central part of the Pervomayskoye deposit,positionof which corresponds to the intersection of two deep faults that are: the submeridional Krivoy Rog-Kremenchug and the sublatitudinal Devladovo ones.

Table 1. Distribution of riebeckite metasomatitesin sections of productive strata of Krivoy Rog basin deposits

\begin{tabular}{|c|c|c|c|}
\hline Deposits & $\begin{array}{c}\text { Distribution, } \\
\text { \% by volume }\end{array}$ & Deposits & $\begin{array}{c}\text { Distribution, } \\
\text { \% by volume }\end{array}$ \\
\hline Annovskoye & 29,9 & Artem-1 Mine & 0,0 \\
\hline Pervomayskoye & 43,6 & Gigant-GlubokayaMine & 0,0 \\
\hline Tyrny Mine & 7,8 & Novokrivorozhskoye & 0,0 \\
\hline Yubileynaya Mine & 3,6 & Valyavkinskoye & 1,4 \\
\hline Gleyevatskoye & 2,1 & Skelyevatskoye & 0,1 \\
\hline FrunzeMine & 1,9 & Ingulets Mine & 2,8 \\
\hline Rodina Mine & 0,1 & Inguletskoye & 3,1 \\
\hline
\end{tabular}

In the productive strata of other deposits of the Krivbass, the distribution of riebeckite metasomatites is 1-2 orders lower in comparison with the indicators of Pervomayskoye and Annovskoye deposits. But their position is also determined by the position of faults.

Thus, the stratigraphic and tectonicfactors of localization of riebeckite metasomatites within the boundaries of Krivoy Rog region are the main ones.

Deposits. Regularities in the distribution of riebeckite metasomatites in ferruginous rocks of individual deposits of the Krivoy Rogbasin were considered earlier (Eliseyev, e. a., 1961; Kushev,1972; Evtekhov, e. a., 1980;Evtekhov, e. a., 1988). Previous authors came to the conclusion that the rocks of ferruginous and schistous horizons were subject to varying degrees of metasomatic alterations, including riebeckitization process.

A detailed study of the geological position of riebeckite metasomatites in the Saksagan suite section has been carried out by the authors of this article for the Pervomayskoye deposit. It was chosenamong the deposits of Krivbass as the main object of research due to the greatest distribution of sodium, including riebeckite metasomatites, in its productive stratum. The section of the iron ore Saksagan suite consists of five ferruginous (the first, second, fifth, sixth, seventh) and five schistose horizons (the first, second, third- fifth, sixth, seventh) horizons. The distribution of riebeckite metasomatiteswas determined in all ferruginous and schistous horizonsin the faces of the Pervomayskoye open-pit at various hypsometric levels. The results of macroscopic and microscopic assaying confirmed generally the data given in the works of the predecessors, allowed quantifying the variability of the content of riebeckite metasomatites in the productive and enclosing strata of the deposit (Fig. 2). 


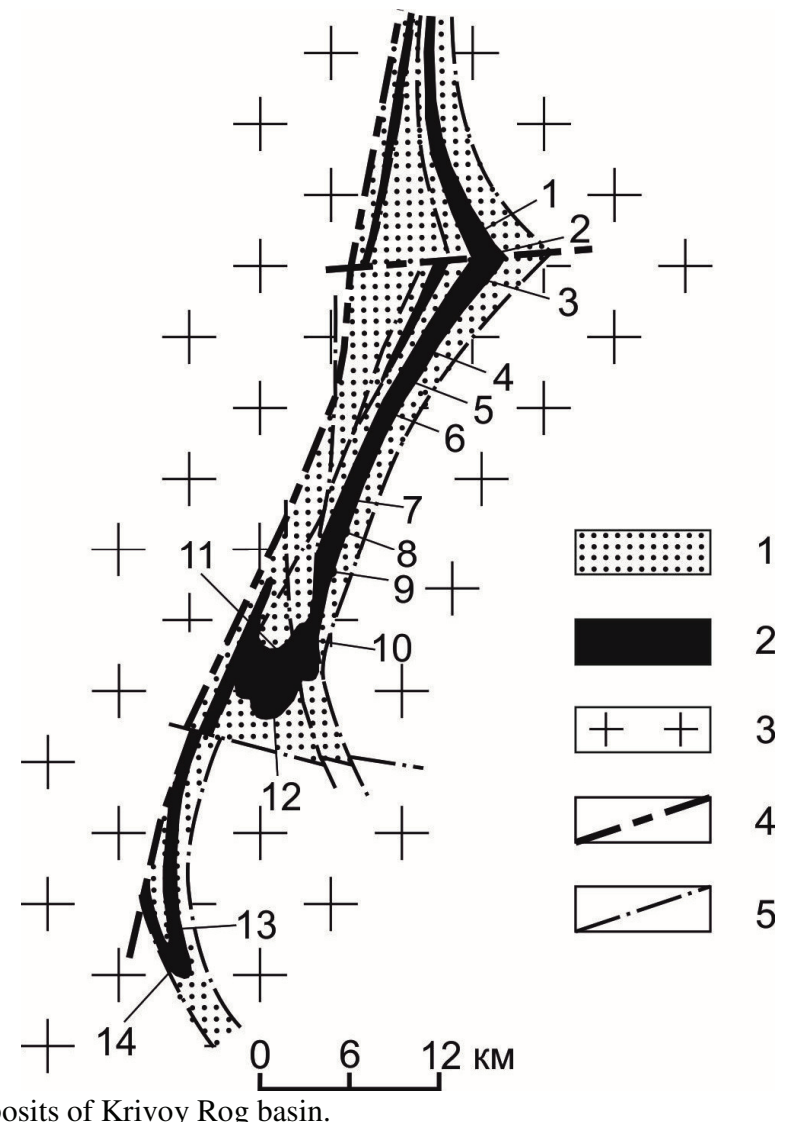

Fig. 1. The position of iron ore deposits of Krivoy Rog basin.

1 - Metamorphic rocks of the Krivoy Rog series; 2 - ferruginous rocks of the Saksagan suite; 3 - granitoids of the Dnipropetrovsk complex; 4 - deep (mantle) faults; 5 - secondary (crustal) breaking disorders.

Deposits: 1 - Annovskoye; 2 - Pervomayskoye; 3 - Tyrny Mine; 4 - Yubileynaya Mine; 5 - Gleyevatskoye; 6 - Frunze Mine; 7 Rodina Mine; 8 - Artem-1 Mine; 9 - Gigant-Glubokaya Mine; 10 - Novokrivorozhskoye; 11 - Valyavkinskoye; 12 - Skelyevatskoye; 13 - Ingulets Mine; 14 - Inguletskoye.

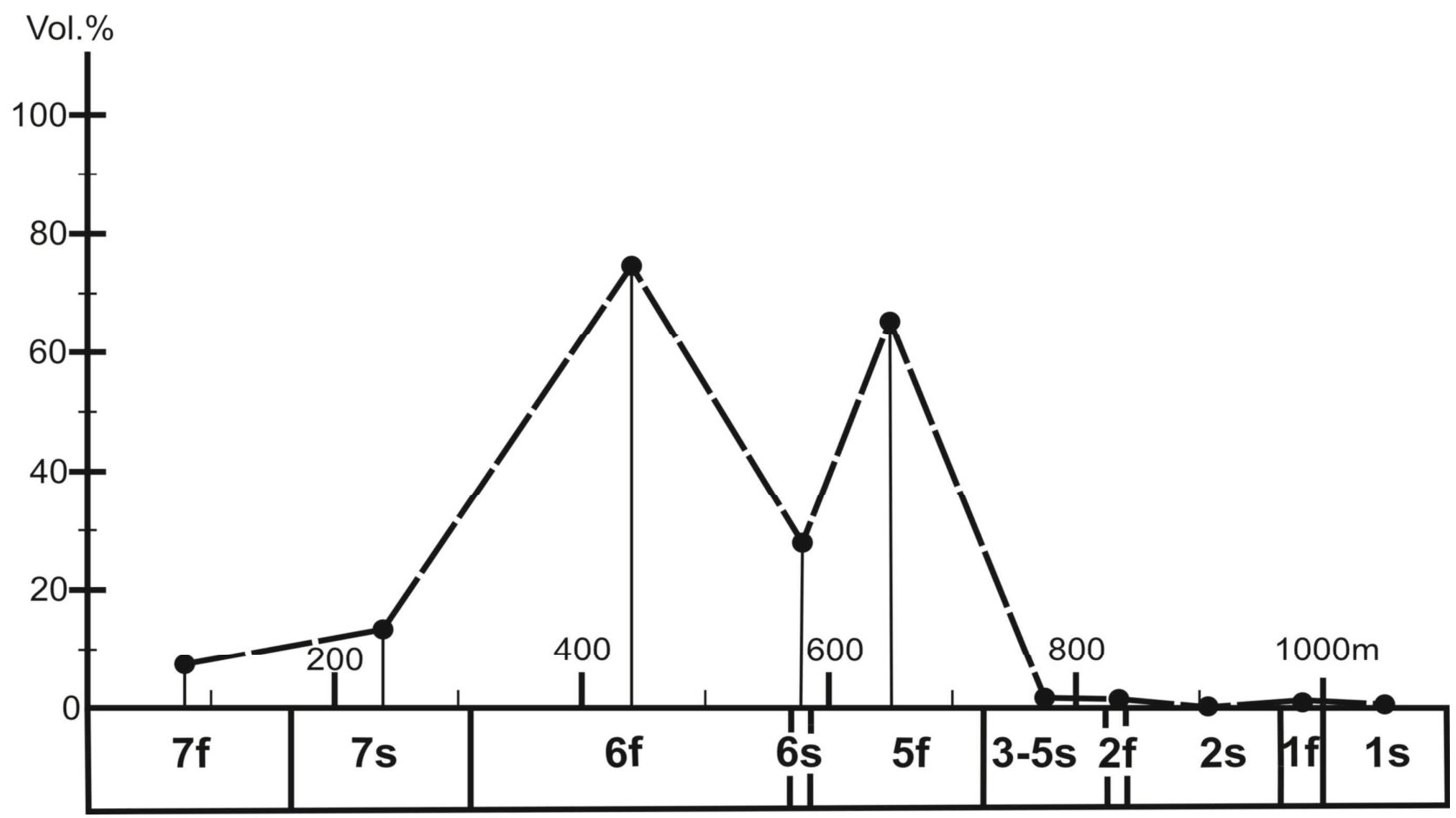

Fig. 2. Distribution of riebeckite metasomatites in the stratigraphic horizons at the Saksagan suite of the Pervomayskoye deposit.

Stratigraphic horizons: $7 \mathrm{f}-$ the seventh ferruginous; $7 \mathrm{~s}$ - the seventh schistose; $6 \mathrm{f}-$ the sixth ferruginous ... 1f - the first ferruginous; $1 \mathrm{~s}-$ is the first schistose. (The figures on the section show the distance from the upper contact of the seventh ferruginous horizon, that is, from the upper contact of the Saksagan suite.) 
The maximum distribution of riebeckite metasomatites is typical for the fifth and sixth horizons, which form the productive iron orerock mass of the deposit. In their sections rather than anywhere else there are ferruginous quartzites with the highest iron content, which are optimal in composition for the active manifestation of riebeckite metasomatism. In the stratigraphic horizons underlying and overlaying the productive rock mass and which are composed of schists and low-iron magnetitesilicate quartzites, riebeckitization was much weaker. In the magnetite-silicate quartzites of the seventh schistose and seventh ferruginous horizons, as well as in the cummingtonite-containing schists of the first and second ferruginous horizons, amphibole, represented by magnesioriebeckite, was formed in areas close to the zones of active manifestation of sodium metasomatism in the productive rock mass of the deposit. In the rocks of the first and second schistose horizons, there are practically no manifestations of the sodium amphibole, locally Vol.\%

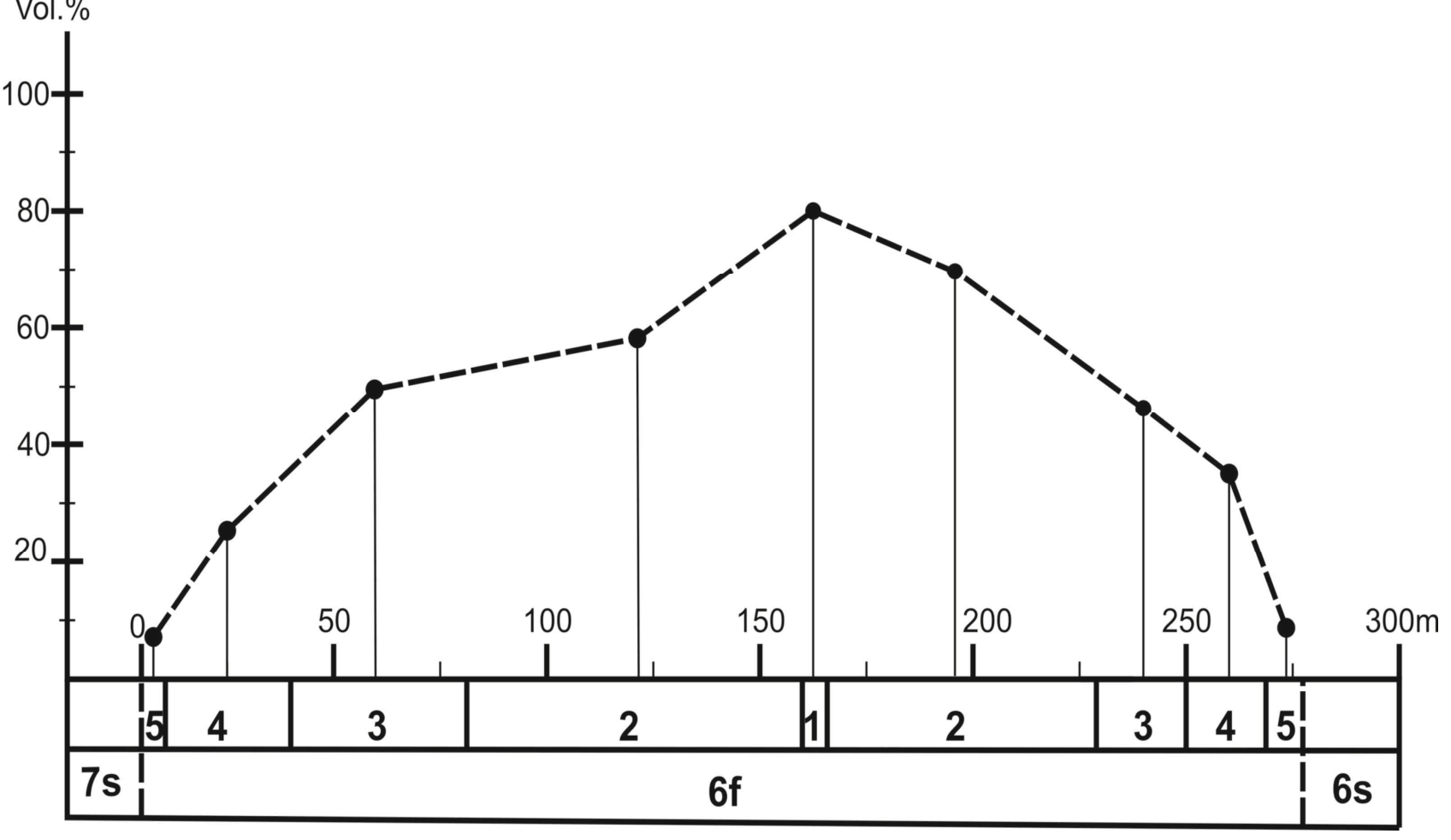

Fig. 3. Distribution of riebeckite metasomatites in strata of different initial mineral composition of ferruginous quartzites, which form the section of the sixth ferruginous horizon of the Pervomayskoye deposit.

Stratigraphic horizons: $7 \mathrm{~s}$ - the seventh schistouse; $6 \mathrm{f}$ - the sixth ferruginous; $6 \mathrm{~s}$ - the sixth schistous.

Mineral varieties of primary ferruginous quartzites: 1 - micaceous hematite-magnetite; 2 - magnetite red-layered(micaceous hematite-containing); 3 - magnetite grey-layered (cummingtonite-containing); 4 - cummingtonite-magnetite; 5 - magnetitecummingtonite. (The figures on the section show the distance from the upper contact of the sixth ferruginous horizon of the Saksagan suite.)

The horizon section is composed of layers of the main mineral varieties of ferruginous quartzites being present in the ferruginous horizons of the productive strata at all deposits in the basin. The central zone is represented by a thin layer of micaceous hematite-magnetite quartzites. In the direc- it occurs only in the peripheral zones of these horizons adjacent to the riebeckitization zones of magnetite-cummingtonite, cummingtonite-magnetite quartzites of the first and second ferruginous horizons.

Geological studies of other deposits in the Krivoy Rog basin withnoticeable distribution of riebeckite metasomatites (Annovskoye, Gleyevatskoye, Valyavkinskoye and Inguletskoye) confirmed the regularity found for the Pervomayskoye deposit. The maximum content of riebeckite is typical for the most powerful ferruginous horizons with the highest iron content. For the Annovskoye deposit, it is the combined fifth to sixth ferruginous horizon; for Gleyevatskoye one- the fourth, fifth and sixth ferruginous horizons; for Valyavkinskoye- the fourth ferruginous horizon; for Inguletskoye- the second, fourth, fifth and sixth ferruginous horizons. Ferruginous horizons. The major part of the research was carried out for the sixth ferruginous horizon of the Pervomayskoye deposit (Fig.3). 
lutionary contacts with the layers of biotite-quartzcummingtonite schists of the sixth schistose horizon (footwall) and magnetite-biotite-cummingtonite quartzite of the seventh schistose horizon (hanging wall).

The greatest distribution of riebeckite is typical for the strata and lenticular bodies of micaceous hematite -magnesite quartzites, which have undergone a practically complete riebeckitization within the Pervomayskoye deposit (Fig. 3). Earlier it was noted (Evtekhov, e. a., 1988) that micaceous hematite-magnetite quartzites were thermodynamically the most favorable for metasomatic formation of riebeckite.Riebeckite metasomatites are less commonin the layers of magnetite quartzites, moreover, the red-layeredmicaceous hematite-containing varieties have been subjected to more active riebeckitization as compared to cummingtonitecontaining grey-layeredones.

In the layers composed of cummingtonitemagnetite and magnetite-cummingtonite quartzites, the amount of riebeckite metasomatites is much lower $-10-30 \%$ of the total volume of the layers. Thesodium-

amphiboleisrepresentedherebymagnesioriebeckite.

Similar regularities in the distribution of riebeckite metasomatites are also typical for the fifth ferruginous horizon of the Pervomayskoye deposit, the fifth and sixth ferruginous horizons of the Annovskoye deposit, the fourth ferruginous horizon of the Valyavkinskoye deposit, the second, fifth and sixth ferruginous horizons of the Inguletskoye deposit.

\section{Conclusions.}

1. Riebeckite metasomatites belong to the most common mineral varieties of magnetite ores of Pervomayskoye, Annovskoye, Petrovskoye, Artemovskoye, Inguletskoye and several other deposits of the Krivoy Rog basin.

2. In order to improve the efficiency of geological-mineralogical, geological-technological mapping of productive strata of deposits, blending ores prior to feeding to beneficiation plants,peculiarities of geological position of riebeckite metasomatitesbodies were studied.

3. Within the Krivoy Rog basin and individual deposits, the leading factors for localization of riebeckite metasomatites were as follows: 1)the tectonic one, the action of which provided metasomatic solutions; 2) the stratigraphic one, the value of which consisted in the formation of riebeckite metasomatites, mainly in ferruginous horizons with the maximum total iron content and minimum silicate content.

4. In the sections of the ferruginous horizons, the layers of their central zones,represented by micaceous hematite-magnetite, magnetite quartzites, were subjected to maximum riebeckitization. The intensity of riebeckitization of well represented silicate-magnetite and magnetitesilicate quartzites in this area decreased substantiallyin the direction toward the peripheral zones of the horizons.

\section{References}

Aleksandrov I.V., 1963. Natrovyiy metasomatoz v Krivorozhe [Sodium metasomatosis in Krivorozhye.Geochemistry of alkali metasomatosis]. Moscow: Publ. house of USSR Acad. of Sci., 71-151 (in Russian).

Evtekhov V.D. Poltavets L.I., 1980. Ob osobennostyah sostava i svoystv ribekitov Severnogo Krivorozhya [Concerning peculiarities of composition and properties of riebeckites of the Northern Krivorozhye]. Reports of the UkrSSR Academy of sciences.Series B, №5, 13-15 (in Russian).

Evtekhov V.D., Zarayskiy G.P., Balashov V.N., Valeyev O.K., 1988. Zonalnost natriyevyh metasomatitov v zhelezistyh kvartsitah Severnogo Krivorozhya [Zoning of sodium metasomatites in ferruginous quartzites of the Northern Krivorozhye]. Physicochemical petrology essays. Moscow: Nauka, №15, 17-37 (in Russian).

Eliseyev, N.A., Nikolskiy, A.P., Kushev, V.G. (1961). Metasomatity Krivorozhskogo rudnogo poyasa [Metasomatites of Krivoy Rog ore belt]. Works of Laboratory of Precambrian geology of Acad. of Sci. of the USSR, Moscow-Leningrad: Publ. house of Acad. of Sci. of the USSR, is.13, 204 (in Russian).

Kushev V.G. (1972). Shchelochnyye metasomatity dokembriya [Alkaline metasomatites of the Precambrian]. Leningrad: Nedra, 190 (in Russian).

Nikolskiy A.P., 1973. Natriyeviye hydrotermalnye metasomatity yugo-zapadnoy chasty Russkoy platformy [Sodium hydrothermal metasomatites of south-western part of the Russian platform].Geological journal, №2, 31-44 (in Russian).

Pirogov B.I., Stebnovskaya Yu.M., Evtekhov V.D., 1989. Zhelezisto-kremnistiye formatsiyi dokembriya yevropeyskoy chasty SSSR. Mineralogiya [Precambrian banded iron formations of the $\mathrm{Eu}-$ ropean part of the USSR].Mineralogy. Kiev: Naukova dumka, 168 (in Russian).

Polovinkina Yu.Ir., 1953. Kummingtonit i shchelochniye amfiboly Krivogo Roga [Cummingtonite and alkaly amphiboles of Krivoy Rog]. Mineralogical digest (Lvov), №7, 167-186 (in Russian).

Chadwick B., Garrioch N.H.G., Ramakrishnan M., Viswanatha M.N., 1986. Mineral composition, textures and deformation in Late Archean banded iron-formation rich in magnesioriebeckite and aegirine, Bababudan, Karnataka, Southern India. J. Geol. Soc. India, 28, №2-3, 189-200. 